\title{
Clustering Kanker Serviks Berdasarkan Perbandingan Euclidean dan Manhattan Menggunakan Metode K-Means
}

\author{
Slamet Widodo, ${ }^{1, *}$,Herlambang Brawijaya ${ }^{1}$, Samudi $^{2}$ \\ ${ }^{1}$ Teknik dan Informatika, Sistem Informasi (D3), Universitas Bina Sarana Informatika, Jakarta, Indonesia \\ ${ }^{2}$ Prodi Sistem Informasi, STMIK Nusa Mandiri, Jakarta, Indonesia \\ Email: 1," slamet.smd@bsi.ac.id, ${ }^{2}$ herlambang.hba@bsi.ac.id, ${ }^{3}$ samudi.smx @ nusamandiri.ac.id \\ Email Penulis Korespondensi: slamet.smd@bsi.ac.id
}

\begin{abstract}
Abstrak-K-means algoritma pengklasteran yang cukup sederhana dan biasa digunakan untuk mempartisi dataset kedalam beberapa klaster k. Perhitungan jarak digunakan untuk menemukan objek data serupa yang mengarah untuk mengembangkan algoritma yang kuat untuk datamining seperti klasifikasi dan pengelompokan. Beberapa penelitian menerapkan algoritma kmeans menggunakan perhitungan jarak seperti Euclidean, Manhattan dan Minkowski. Penelitian ini menggunakan dataset dari pasien gynekologi dengan jumlah data sebanyak 401 pasien yang diperiksa dan sebanyak 205 pasien yang terdeteksi kanker serviks, sedangkan 196 pasien lainnya tidak terkena kanker serviks. Hasil ditampilkan dengan bantuan confusion matrix dan kurva ROC, Nilai akurasi didapat sebesar 79,30\% dengan ROC 79,17\% pada K-Means Euclidean Metric sedangkan K-Means Manhattan Metric sebesar 67,83\% dengan ROC 65,94\%. Dengan demikian dapat disimpulkan bahwa metode Euclidean merupakan metode terbaik untuk diterapkan dalam algoritma $K$-Means Clustering pada dataset kanker serviks.
\end{abstract}

Kata Kunci: Serviks; K-Means; Euclidean; Manhattan; Kluster

Abstract-K-means a fairly simple and commonly used cluster of clusters to partition datasets into multiple clusters. Distance calculations are used to find similar data objects that lead to developing powerful algorithms for datamining such as classification and grouping. Some studies apply k-means algorithms using distance calculations such as Euclidean, Manhattan and Minkowski. The study used datasets from gynecological patients with a total of 401 patients examined and as many as 205 patients detected cervical cancer, while 196 other patients did not have cervical cancer. The results were shown with the help of confusion matrix and ROC curve, accuracy value obtained by $79.30 \%$ with ROC $79.17 \%$ on K-Means Euclidean Metric while K-Means Manhattan Metric by $67.83 \%$ with ROC $65.94 \%$. Thus it can be concluded that the Euclidean method is the best method to be applied in the K-Means Clustering algorithm on cervical cancer datasets.

Keywords: Cervix; K-Means; Euclidean; Manhattan; Cluster

\section{PENDAHULUAN}

Menjaga kesehatan organ reproduksi, memberikan pengaruh yang besar bagi kelangsungan hidup demi menjaga kelanjutan generasi suatu bangsa. Salah satu masalah pada kesehatan reproduksi pada wanita adalah ditemukannya kanker mulut rahim atau kanker serviks. Kanker serviks merupakan kanker yang paling sering terjadi pada perempuan Indonesia, diperkirakan 52 juta perempuan Indonesia berisiko terkena kanker serviks, sementara 36\% perempuan dari seluruh penderita kanker adalah pasien kanker serviks [1]. Kanker serviks merupakan kanker ginekologi tersering terjadi pada wanita. Diindonesia lebih dari 15.000 kasus baru kanker serviks dan hampir 8000 kematian yang disebabkan oleh kanker ini [2]. Setiap tahun, lebih dari setengah juta wanita didiagnosis dengan kanker serviks dan penyakit ini menyebabkan lebih dari 300.000 kematian di seluruh dunia [3].

Kanker seviks adalah tumor ganas primer yang berasal dari sel epitel skuamosa. Sebelum terjadinya kanker, akan didahului oleh keadaan yang disebut lesi prakanker atau neoplasia intraepitel serviks (NIS). Salah satu penyebabnya terinfeksi virus Human papillomavirus (HPV) tipe 16 dan 18 yang persisten [4]. Perempuan yang rawan mengidap kanker serviks adalah mereka yang berusia antara 35 sampai dengan 50 tahun, terutama wanita yang telah aktif secara seksual sebelum usia 16 tahun. Hubungan seksual pada usia terlalu dini dan yang mempunyai banyak pasangan bisa meningkatkan risiko terserang kanker leher rahim [5]. Skrining deteksi dini sangat penting untuk tetap dilakukan, walaupun sudah dilakukan vaksinasi HPV karena vaksinasi HPV tidak bisa menyembuhkan seseorang yang telah terinfeksi HPV atau disebabkan oleh vaksin HPV yang saat ini tersedia belum menjangkau seluruh tipe HPV penyebab kanker serviks [6].

Salah satu tugas utama untuk diagnosis yang akurat adalah ekstraksi pengetahuan yang berguna dari data diagnosis masa lalu. Teknik mesin pembelajaran memungkinkan komputer untuk belajar dari pengalaman dan contoh pola masa lalu. Dengan demikian, penggunaan alat-alat mesin pembelajaran dalam diagnosis medis meningkat secara bertahap. Teknik data mining dan soft computing diterapkan untuk mengekstrak aturan dan pola dari berbagai dataset, beberapa teknik ini telah menunjukkan hasil yang sangat baik dalam masalah datamining, yang dapat membantu ahli medis dalam mengenali penyakit. Tujuan yang paling penting dari aplikasi data mining dalam diagnosis adalah deteksi akurat, diagnosis dini dan identifikasi faktor risiko. Hasil dari prosedur ini menjadi dasar dari pemilihan metode pengobatan yang tepat [7].

Clustering memiliki banyak algoritma, seperti yang berbasis partisi (Kmeans, Partitioning Around Medoids (PAM), Fuzzy C-Means (FCM), K-mode), berbasis hierarki (CURE, Bunglon, BIRCH), yang berbasis density (DBSCAN, DENCLUE, OPTICS), yang berbasis grid (termasuk STING, OptiGrid, CLIQUE) 
dan yang berbasis model ( $C O B W E B, C L A S S I T, E M)$ [8], namun pada penelitian yang telah dilakukan sebelumnya menyebutkan bahwa clustering menggunakan algoritma $K$-Means paling sering digunakan karena memiliki kelebihan yaitu algoritmanya sangat sederhana, mudah untuk di implementasikan. Dan merupakan salah satu metode yang cukup efisien dalam menangani kompleksitas [9]. Algoritma K-Means dimulai dengan pembentukan partisi klaster di awal kemudian secara iteratif partisi klaster ini diperbaiki hingga tidak terjadi perubahan yang signifikan pada tiap partisi klaster [7].

Metode perhitungan jarak digunakan untuk menemukan objek data serupa yang mengarah untuk mengembangkan algoritma yang kuat untuk fungsi klasifikasi dan pengelompokan datamining, diantaranya Manhattan, Euclidean dan Minkowski dibandingkan untuk menemukan metode perhitungan jarak yang paling baik, hasil penelitian menyimpulkan bahwa metode perhitungan jarak Euclidean lebih baik dari pada metode Manhattan [10]. Untuk mengukur kesamaan atau keteraturan antara data-item, jarak metrik memainkan peran yang sangat penting. Perhitungan jarak bagian penting dalam banyak metode pembelajaran seperti $K$-Means, $K N N$ dan Learning Vector Quantization [11]. Metode perhitungan serupa pernah dilakukan oleh [12] pada algoritma $K$ Means dengan menggunakan pengujian chi-square untuk pelabelan klaster status disparitas kebutuhan guru dan. Hasil pengujian menunjukkan bahwa metode Euclidean distance lebih baik dari pada metode Manhattan dan Minskowski.

Berdasarkan uraian diatas, penelitian ini mengimplementasikan pengukuran jarak menggunakan metode Euclidean dan Manhattan pada algoritma K-Means berbasis Confusion Matrix dan ROC Curve (AUC) untuk mengevaluasi hasil akurasi terbaik dari jarak kedua metode tersebut.

\section{METODOLOGI PENELITIAN}

\subsection{Tahapan Metodologi Penelitian}

Penelitian ini menggunakan penelitian eksperimen. Penelitian eksperimen melibatkan penyelidikan perlakuan pada parameter atau variabel tergantung dari penelitinya dan menggunakan tes yang dikendalikan oleh si peneliti itu sendiri, dengan metode penelitian sebagai berikut:

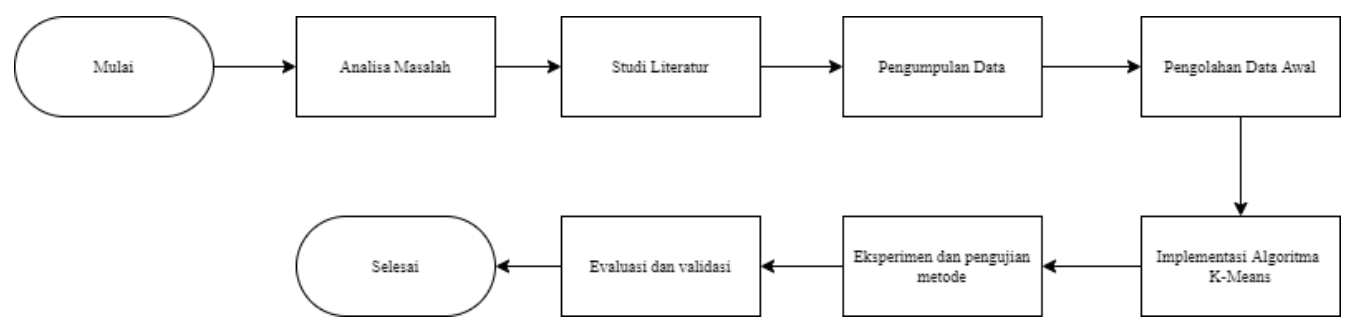

Gambar 1. Metodologi Penelitian

Berdasarkan gambar 1 diatas dapat dijelaskan proses tahapan metodologi penelitian untuk clustering kanker serviks:

1. Analisa masalah

Masalah yang menjadi pokok penelitian adalah mencari pengukuran jarak terbaik menggunakan metode Euclidean dan Manhattan pada pengelompokan data set kanker serviks. Sehingga dapat terbentuk suatu partisi/klaster yang mirip satu sama lain pada masing-masing partisi.

2. Studi Literatur

Penelitian ini didasari rujukan yang digunakan untuk mendapatkan informasi dan teori yang mendukung penelitian.

3. Pengumpulan Data

Pada tahap ini ditentukan data yang akan diproses. Mencari data yang tersedia, memperoleh data tambahan yang dibutuhkan, mengintegrasikan semua data kedalam data set, termasuk variabel yang diperlukan dalam proses. Data yang digunakan adalah data pasien gynekologi dengan jumlah data sebanyak 401 pasien.

4. Pengolahan Data awal

Data yang telah dikumpulakan selanjutnya dianalisa dengan menyeleksi data yang meliputi pembersihan data dengan membuang data yang tidak konsisten dan pembersihan data yang tidak lengkap (missing value) dan melakukan transformasi data dibutuhkan dalam proses penyelesaian masalah.

5. Implementasi Algoritma K-Means

Pada penelitian ini, algoritma $K$-Means digunakan untuk mendapatkan kualitas cluster yang optimal dengan menentukan atau mendeskripsikan tingkat kemiripan atau ketidakmiripan data, sehingga perlu dilakukannya perbandingan beberapa metode yang sering digunakan, yaitu jarak Euclidean dan Manhattan.

6. Eksperimen dan Pengujian Metode 
Perbandingan metode perhitungan jarak Euclidean dan Manhattan pada algoritma K-Means dilakukan untuk mengetahui nilai sensitivity (recall), specificity, precision dan accuracy dan AUC tertinggi dengan menggunakan dataset medis (kanker serviks) dan diuji menggunakan tool WEKA.

7. Evaluasi dan Validasi

Pada tahap ini dilakukan evaluasi terhadap model yang ditetapkan untuk mengetahui tingkat kemiripan atau ketidakmiripan data antar cluster dengan menggunakan pengukuran confussion Matrix dan kurva ROC.

\subsection{Analisa Data}

Data yang digunakan dalam penelitian ini adalah data sekunder yang diperoleh dari RSPAD Gatot Soebroto Jakarta yang diambil oleh Ridwansyah dalam penelitiannya mengenai mioma uteri. Data pasien gynekologi dengan jumlah data sebanyak 401 pasien yang diperiksa dan sebanyak 205 pasien yang terdeteksi kanker serviks, sedangkan 196 pasien lainnya tidak terkena kanker serviks. Data kanker serviks terdri dari 15 variabel atau atribut. Variabel tersebut yaitu: umur, sistol, diastol, suhu, nadi, pernapasan, status, pendarahan_setelah_senggama, keluarnya_tinja_melalui_vagina, menstruasi_lebih_lama, keputihan, sering_lelah, keluar_air_kemih, pembengkakan_area_kaki, nyeri_tulang_panggul_dan_belakang. Berikut adalah data penelitian yang ditunjukkan pada tabel 1 .

Tabel 1. Data Pasien gynekologi

\begin{tabular}{|c|c|c|c|c|c|c|c|c|c|c|c|c|c|}
\hline \multirow[b]{2}{*}{ Sistol } & \multirow[b]{2}{*}{ Diastol } & \multirow[b]{2}{*}{ Suhu } & \multicolumn{11}{|c|}{ Keluarnya } \\
\hline & & & Nadi & $\begin{array}{c}\text { Perna- } \\
\text { pasan }\end{array}$ & Umur & $\begin{array}{c}\text { Meni- } \\
\text { kah }\end{array}$ & $\begin{array}{c}\text { Pendarahan } \\
\text { Setelah } \\
\text { Senggama }\end{array}$ & $\begin{array}{c}\text { Tinja } \\
\text { Melalui } \\
\text { vagina }\end{array}$ & $\begin{array}{l}\text { Menstruasi } \\
\text { Lebih Lama } \\
\text { dan Banyak }\end{array}$ & $\begin{array}{c}\text { Kepu- } \\
\text { tihan }\end{array}$ & $\begin{array}{l}\text { Sering } \\
\text { Lelah }\end{array}$ & $\ldots$ & Hasil \\
\hline 140 & 90 & 36 & 88 & 20 & 43 & $\mathrm{Ya}$ & Tidak & Tidak & Tidak & Tidak & Tidak & $\ldots$ & Miom \\
\hline 140 & 90 & 36 & 85 & 21 & 45 & $\mathrm{Ya}$ & $\mathrm{Ya}$ & Tidak & $\mathrm{Ya}$ & Ya & Ya & $\ldots$ & Serviks \\
\hline 120 & 80 & 36 & 80 & 20 & 39 & $\mathrm{Ya}$ & $\mathrm{Ya}$ & $\mathrm{Ya}$ & $\mathrm{Ya}$ & $\mathrm{Ya}$ & $\mathrm{Ya}$ & $\ldots$ & Miom \\
\hline 100 & 70 & 38 & 80 & 20 & 43 & $\mathrm{Ya}$ & Tidak & $\mathrm{Ya}$ & $\mathrm{Ya}$ & $\mathrm{Ya}$ & $\mathrm{Ya}$ & $\ldots$ & Serviks \\
\hline 120 & 78 & 36 & 85 & 21 & 61 & $\mathrm{Ya}$ & $\mathrm{Ya}$ & $\mathrm{Ya}$ & $\mathrm{Ya}$ & Ya & Tidak & $\ldots$ & Serviks \\
\hline$\cdots$ & $\cdots$ & $\cdots$ & $\cdots$ & $\cdots$ & $\cdots$ & $\cdots$ & $\cdots$ & $\cdots$ & $\cdots$ & $\cdots \cdot$ & $\cdots$ & $\begin{array}{l}\ldots . \\
\text { Ser }\end{array}$ & $\cdots$ \\
\hline 130 & 90 & 36 & 86 & 20 & 51 & $\mathrm{Ya}$ & Tidak & $\mathrm{Ya}$ & $\mathrm{Ya}$ & $\mathrm{Ya}$ & $\mathrm{Ya}$ & viks & Serviks \\
\hline
\end{tabular}

\subsection{Data Mining}

Data mining merupakan analisis dari kumpulan data untuk menemukan hubungan yang tidak diduga dan meringkas data dengan cara yang berbeda dengan sebelumnya, yang dapat dipahami dan bermanfaat bagi pemilik data [13]. Datamining didefinisikan sebagai proses menemukan pola dalam data. Prosesnya bisa otomatis atau semi-otomatis, pola yang ditemukan harus bermakna [7].

\subsection{Algoritma K-Means}

Algoritma K-Means adalah algoritma pengelompokan iterasi sederhana, jumlah cluster tergantung pada pengaturan nilai K [14]. Berikut tahapan algoritma K-Means [13]:

a) Menentukan jumlah cluster $\mathrm{k}$ dataset yang harus dipartisi

b) Pilih secara acak k point untuk dijadikan pusat cluster.

c) Untuk setiap record, temukan pusat cluster terdekat. Jadi, dalam arti tertentu, masing-masing pusat cluster "memiliki" subset dari record, dengan demikian merepresentasikan sebuah partisi dari kumpulan data.

d) Untuk setiap cluster k, temukan pusat cluster, dan perbarui lokasi setiap pusat cluster ke nilai baru dari centroid.

e) Ulangi langkah hingga data di dalam segmentasi tidak berubah.

Langkah penting dalam pengelompokan adalah memilih perhitungan jarak, yang akan meningkatkan hasil algoritma berbasis jarak [15]. Hal ini diperlukan untuk mengidentifikasi, dengan cara apa data tersebut saling terkait, bagaimana berbagai data berbeda atau serupa satu sama lain dan ukuran apa yang dipertimbangkan untuk perbandingannya. Inilah tujuan utama perhitungan jarak dalam memecahkan masalah tertentu. Dalam penelitian ini perhitungan jarak menggunakan metode Euclidean dan Manhattan.

\section{Euclidean Distance}

Euclidean distance merupakan salah satu metode perhitungan jarak yang digunakan untuk mengukur jarak dari 2(dua) buah titik dalam Euclidean space [12].

$$
d(x, y)=|x-y|=\sqrt{\sum_{i=1}^{n}\left(x_{i}-y_{i}\right)^{2}}
$$

Keterangan: 


\section{JURNAL MEDIA INFORMATIKA BUDIDARMA}

Volume 5, Nomor 2, April 2021, Page 687-694

ISSN 2614-5278 (media cetak), ISSN 2548-8368 (media online)

Available Online at https://ejurnal.stmik-budidarma.ac.id/index.php/mib

DOI 10.30865/mib.v5i2.2947

$\mathrm{d}=$ jarak antara $\mathrm{x}$ dan $\mathrm{y}$

$\mathrm{x}=$ data pusat klaster

$\mathrm{y}=$ data pada atribut

$\mathrm{i}=$ setiap data

$\mathrm{n}=$ jumlah data,

$\mathrm{xi}=$ data pada pusat klaster ke $\mathrm{i}$

$\mathrm{yi}=$ data pada setiap data ke $\mathrm{i}$

\section{Manhattan Distance}

Manhattan distance digunakan untuk menghitung perbedaan absolut (mutlak) antara koordinat sepasang objek [12].

Keterangan:

$$
d(x, y)=\sqrt{\sum_{i=1}^{n}\left|x_{i}-y_{i}\right|}
$$

$\mathrm{d}=$ jarak antara $\mathrm{x}$ dan $\mathrm{y}$

$\mathrm{x}=$ data pusat klaster

$\mathrm{y}=$ data pada atribut

$\mathrm{X}_{\mathrm{i}}=$ data pada pusat klaster ke $\mathrm{i}$

$\mathrm{y}_{\mathrm{j}}=$ data pada setiap data $\mathrm{ke} \mathrm{i}$

\subsection{Evaluasi dan Validasi}

Untuk menguji model, pada penelitian ini, digunakan metode Confusion Matrix, dan kurva ROC (Receiver Operating Characteristic).

1. Confusion Matrix

Confusion Matrix memberikan penilaian performance berdasarkan objek dengan benar atau salah [16]. Confusion Matrix berisi informasi aktual (actual) dan prediksi (predicted), urutan pengujian ditabulasikan dalam Confusion Matrix dimana kelas yang diprediksi ditampilkan dibagian atas matriks dan kelas yang diamati disisi kiri. Setiap sel berisi angka yang menunjukkan berapa banyak kasus yang sebenarnya dari kelas yang diamati.

Tabel 1. Confusion Matrix for a- 2 class model

\begin{tabular}{llll}
\hline CLASSIFICATION & \multicolumn{2}{c}{ PREDICTED CLASS } \\
& & Class $=$ YES & Class $=$ No \\
\hline & Class = Yes & $\begin{array}{l}a \\
(\text { true positive }-\mathrm{TP})\end{array}$ & $\begin{array}{l}b \\
(\text { false negitive }-\mathrm{FN})\end{array}$ \\
OBSERVED CLASS & Class $=\mathrm{No}$ & $\begin{array}{l}c \\
(\text { false positive }-\mathrm{FP})\end{array}$ & \begin{tabular}{l} 
(true negative $-\mathrm{TN})$ \\
\hline
\end{tabular}
\end{tabular}

Keterangan:

True Positive (tp) = proporsi positif dalam data set yang diklasifikasikan positif

True Negative (tn) = proporsi negative dalam data set yang diklasifikasikan negatif

False Positive (fp) = proporsi negatif dalam data set yang diklasifikasikan positif

FalseNegative $(\mathrm{fn})=$ proporsi negative dalam data set yang diklasifikasikan negatif

Setelah data uji dimasukkan ke dalam Confusion Matrix, nilai-nilai yang telah dimasukkan tersebut untuk dihitung jumlah sensitivity (recall), specificity, precision dan accuracy. Sensitivity digunakan untuk membandingkan jumlah TP terhadap jumlah record yang positif sedangkan specificity adalah perbandingan jumlah TN terhadap jumlah record yang negative. Berikut persamaan model Confusion Matrix [16].

$$
\begin{aligned}
& \text { Sensitivity }=\frac{T P}{T P+F N} \\
& \text { Specificity }=\frac{T N}{T N+F P} \\
& P P V=\frac{T P}{T P+F P} \\
& N P V=\frac{T N}{T N+F N} \\
& \text { Accuracy }=\frac{T P+T N}{T P+F N+T N+F P}
\end{aligned}
$$

2. Kurva ROC (Receiver Operating Characteristic)

Curve ROC (Receiver Operating Characteristic) adalah cara lain untuk mengevaluasi akurasi secara visual, untuk merepresentasikan grafis yang menentukan mana yang lebih baik, digunakan metode yang menghitung luas 
daerah dibawah kurva ROC yang disebut AUC (Area Under the ROC Curve) yang diartikan sebagai probabilitas [16]. Sebuah grafik ROC adalah plot dua dimensi dengan proporsi positif salah (fp) pada sumbu X dan proporsi positif benar (tp) pada sumbu Y. Titik $(0,1)$ merupakan klasifikasi yang sempurna terhadap semua kasus positif dan kasus negatif. Nilai positif salah adalah tidak ada ( $\mathrm{fp}=0$ ) dan nilai positif benar adalah tinggi $(\mathrm{tp}=1)$. Titik $(0,0)$ adalah klasifikasi yang memprediksi setiap kasus menjadi negatif $\{-1\}$, dan titik $(1,1)$ adalah klasifikasi yang memprediksi setiap kasus menjadi positif $\{1\}$. Grafik ROC menggambarkan trade-off antara manfaat ('true positives') dan biaya ('false positives') [16].

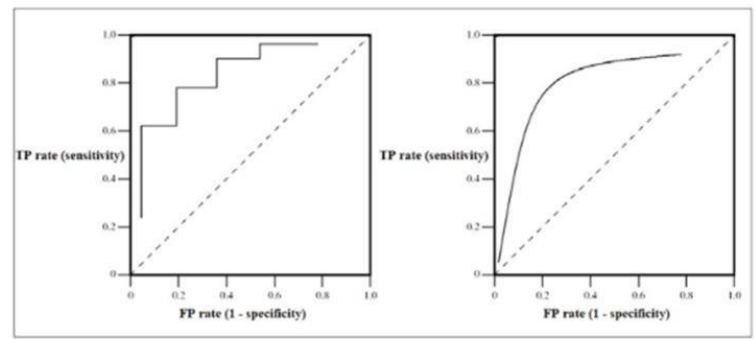

Gambar 2. Grafik ROC

\section{HASIL DAN PEMBAHASAN}

\subsection{Penerapan Algoritma K-Means}

Dalam datamining, clustering digunakan untuk pembagian data, melihat ciri-ciri masing-masing cluster, dan menemukan pusat pada kumpulan cluster tertentu untuk selanjutnya dianalisa. Clustering merupakan bagian penting dalam pengenalan data (recognition), memainkan peran penting dalam menemukan struktur dalam data. Ini dapat berfungsi sebagai langkah pra-pemrosesan untuk algoritma lain.

Sebelum melakukan proses perhitungan, dilakukan normalisasi data yang bertujuan untuk memetakan nilai dari masing-masing variabel ke dalam rentang yang sama yakni rentang [0,1], sehingga pada saat proses perhitungan nilai kemiripan, masing-masing variabel memberikan tingkat kemampuan yang sama.

A. Perhitungan jarak Euclidean

Berikut tahapan Algoritma K-Means dengan Euclidean Metric:

1. Tentukan 'c' pusat kluster secara acak

2. Hitung jarak antara data dan centroid menggunakan persamaan (1)

3. Tetapkan titik data yang jaraknya paling minimum dari pusat cluster

4. Hitung pusat kluster baru menggunakan persamaan:

$$
V_{i}=\left(\frac{1}{C i}\right) \sum_{1}^{C I} x i
$$

di mana, V adalah pusat data dan 'ci' menunjukkan jumlah titik data di kluster ke-i.

5. Hitung ulang setiap partisi yang terbentuk

6. Ulangi langkah hingga data di dalam partisi tidak berubah, jika tidak ulangi langkah 3 hingga 5.

B. Perhitungan jarak Manhattan

Berikut tahapan Algoritma K-Means dengan Manhattan Metric:

1. Tentukan 'c' pusat kluster secara acak

2. Hitung jarak antara data dan centroid menggunakan persamaan (2)

3. Tetapkan titik data yang jaraknya paling minimum dari pusat cluster

4. Hitung pusat kluster baru menggunakan persamaan (4)

5. Hitung ulang setiap partisi yang terbentuk

6. Ulangi langkah hingga data di dalam partisi tidak berubah, jika tidak ulangi langkah 3 hingga 5.

Tabel 3. Jarak Titik Pusat Kluster

\begin{tabular}{|c|c|c|c|c|}
\hline & \multicolumn{2}{|c|}{ Euclidean } & \multicolumn{2}{|c|}{ Manhattan } \\
\hline & $\mathrm{C} 1$ & $\mathrm{C} 2$ & $\mathrm{C} 1$ & $\mathrm{C} 2$ \\
\hline Sistol & 0.4015 & 0.3944 & 0.4 & 0.4 \\
\hline Diastol & 0.6864 & 0.6836 & 0.7087 & 0.6893 \\
\hline Suhu & 0.76 & 0.7653 & 0.75 & 0.75 \\
\hline Nadi & 0.6171 & 0.634 & 0.6168 & 0.6262 \\
\hline Pernapasan & 0.3033 & 0.3128 & 0.2667 & 0.2667 \\
\hline Umur & 0.5158 & 0.5491 & 0.5102 & 0.5102 \\
\hline
\end{tabular}


JURNAL MEDIA INFORMATIKA BUDIDARMA

Volume 5, Nomor 2, April 2021, Page 687-694

ISSN 2614-5278 (media cetak), ISSN 2548-8368 (media online)

Available Online at https://ejurnal.stmik-budidarma.ac.id/index.php/mib DOI 10.30865/mib.v5i2.2947

\begin{tabular}{llrlc}
\hline \multicolumn{1}{c}{ Atribut } & \multicolumn{2}{c}{ Euclidean } & \multicolumn{2}{c}{ Manhattan } \\
& $\mathrm{C} 1$ & $\mathrm{C} 2$ & $\mathrm{C} 1$ & $\mathrm{C} 2$ \\
\hline Menikah & 0.9906 & 0.9787 & 1 & 1 \\
Pendarahan Setelah Senggama & 0.7183 & 0.2181 & 1 & 0 \\
Keluarnya Tinja Melalui vagina & 0.3944 & 0.9309 & 0 & 1 \\
Menstruasi Lebih Lama dan Banyak & 0.5446 & 0.9096 & 1 & 1 \\
Keputihan & 0.6808 & 0.883 & 1 & 1 \\
Sering Lelah & 0.7746 & 0.4734 & 1 & 0 \\
Keluar Air Kemih & 0.662 & 0.8191 & 1 & 1 \\
Pembengkakan Area Kaki & 0.554 & 0.6809 & 1 & 1 \\
Nyeri Tulang Panggul dan belakang & 0.6338 & 0.8404 & 1 & 1 \\
\hline
\end{tabular}

\subsection{Pengujian Cluster dengan Software WEKA}

Pada penelitian ini, proses pengujian menggunakan aplikasi WEKA dengan memanfaatkan tool classificationViaClustering, dimana jumlah kelompok ditentukan sebanyak 2, yaitu serviks dan miom. Algoritma $K$-Means dipilih dengan pengukuran jarak Euclidean. Inisialisasi k ditetapkan secara random, hasil dapat dilihat pada gambar berikut:

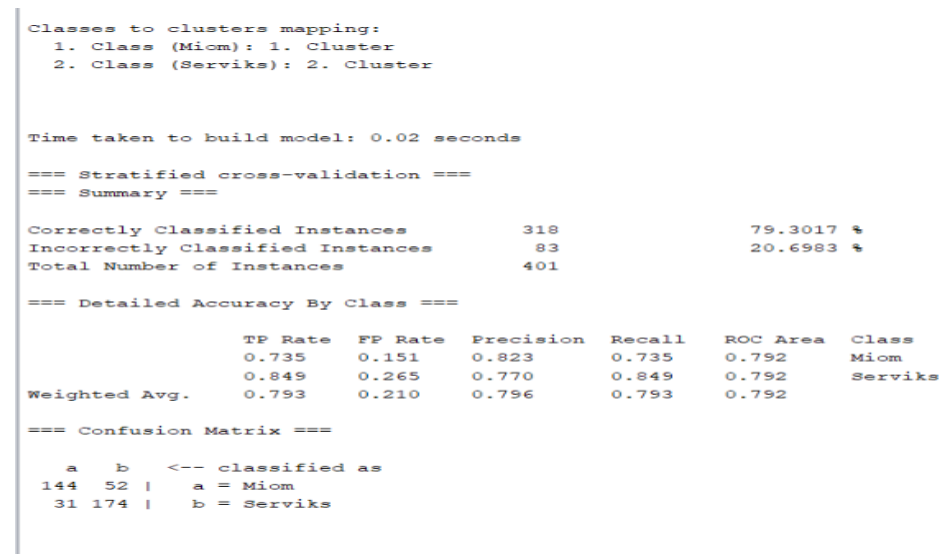

Gambar 3. Hasil Confusion Matrix K-Means Euclidean

Pada gambar Confusion Matrix diatas dapat diketahui ada 174 kasus masuk kedalam kluster benar sebagai serviks ( $t p$ ) dari total 401 kasus, ada 31 kasus yang salah yang seharusnya bukan serviks tetapi masuk ke dalam kluster serviks $(f p)$. Berikutnya ada 144 kasus yang masuk ke dalam kluster benar bukan serviks (tn), dan 52 kasus yang salah yang seharusnya serviks tetapi masuk ke dalam kluster bukan serviks $(f n)$. Untuk mencari nilai accuracy, sensitivity, specificity, $p p v$ dan $n p v$ hasilnya pada persamaan berikut:

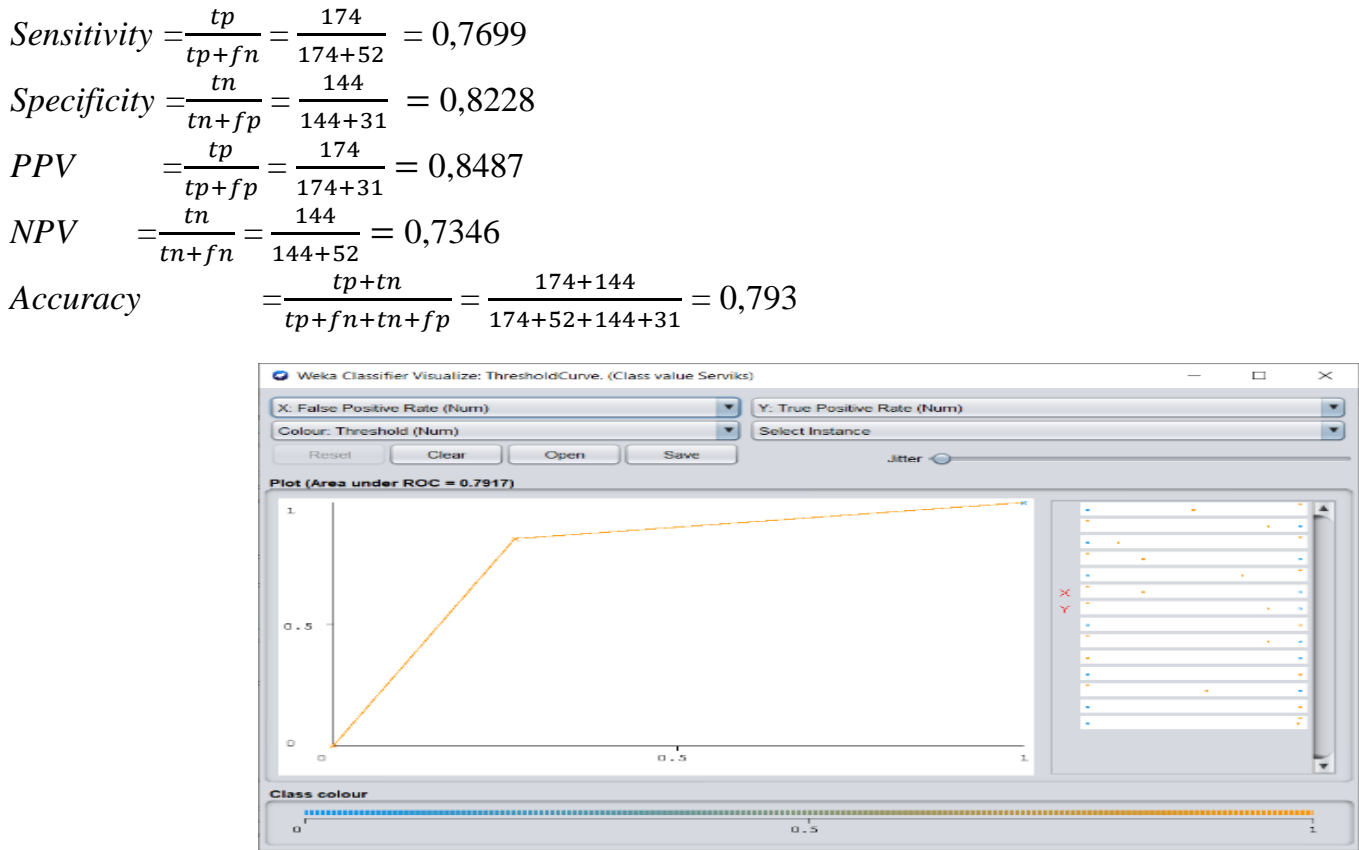

Gambar 4. Hasil AUC Dalam Grafik ROC Algoritma K-Means Euclidean 
JURNAL MEDIA INFORMATIKA BUDIDARMA

Volume 5, Nomor 2, April 2021, Page 687-694

ISSN 2614-5278 (media cetak), ISSN 2548-8368 (media online)

Available Online at https://ejurnal.stmik-budidarma.ac.id/index.php/mib DOI 10.30865/mib.v5i2.2947

Selanjutnya Algoritma K-Means dipilih dengan pengukuran jarak Manhattan. Inisialisasi k ditetapkan secara random, hasil dapat dilihat pada gambar berikut:

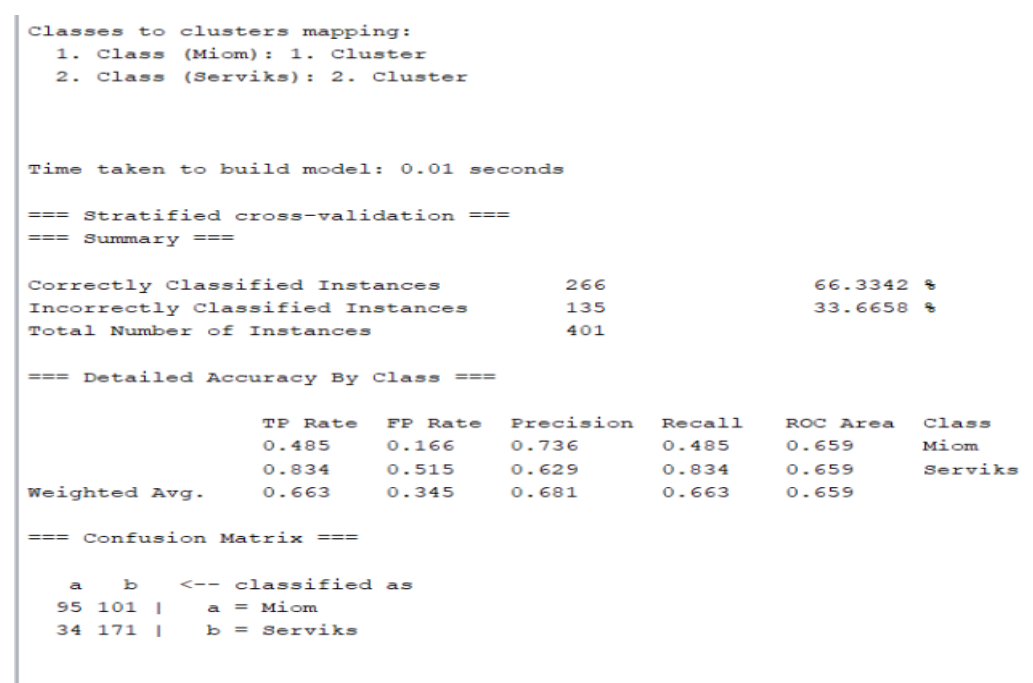

Gambar 5. Hasil Confusion Matrix K-Means Manhattan

Hasil Confusion Matrix mencatat 171 kasus masuk kedalam kluster benar sebagai serviks (tp) dari total 401 kasus, ada 34 kasus yang salah yang seharusnya bukan serviks tetapi masuk ke dalam kluster serviks $(f p)$. Berikutnya ada 101 kasus yang masuk ke dalam kluster benar bukan serviks ( $t n)$, dan 95 kasus yang salah yang seharusnya serviks tetapi masuk ke dalam kluster bukan serviks $(f n)$. Untuk mencari nilai accuracy, sensitivity, specificity, $p p v$ dan $n p v$ hasilnya pada persamaan berikut:

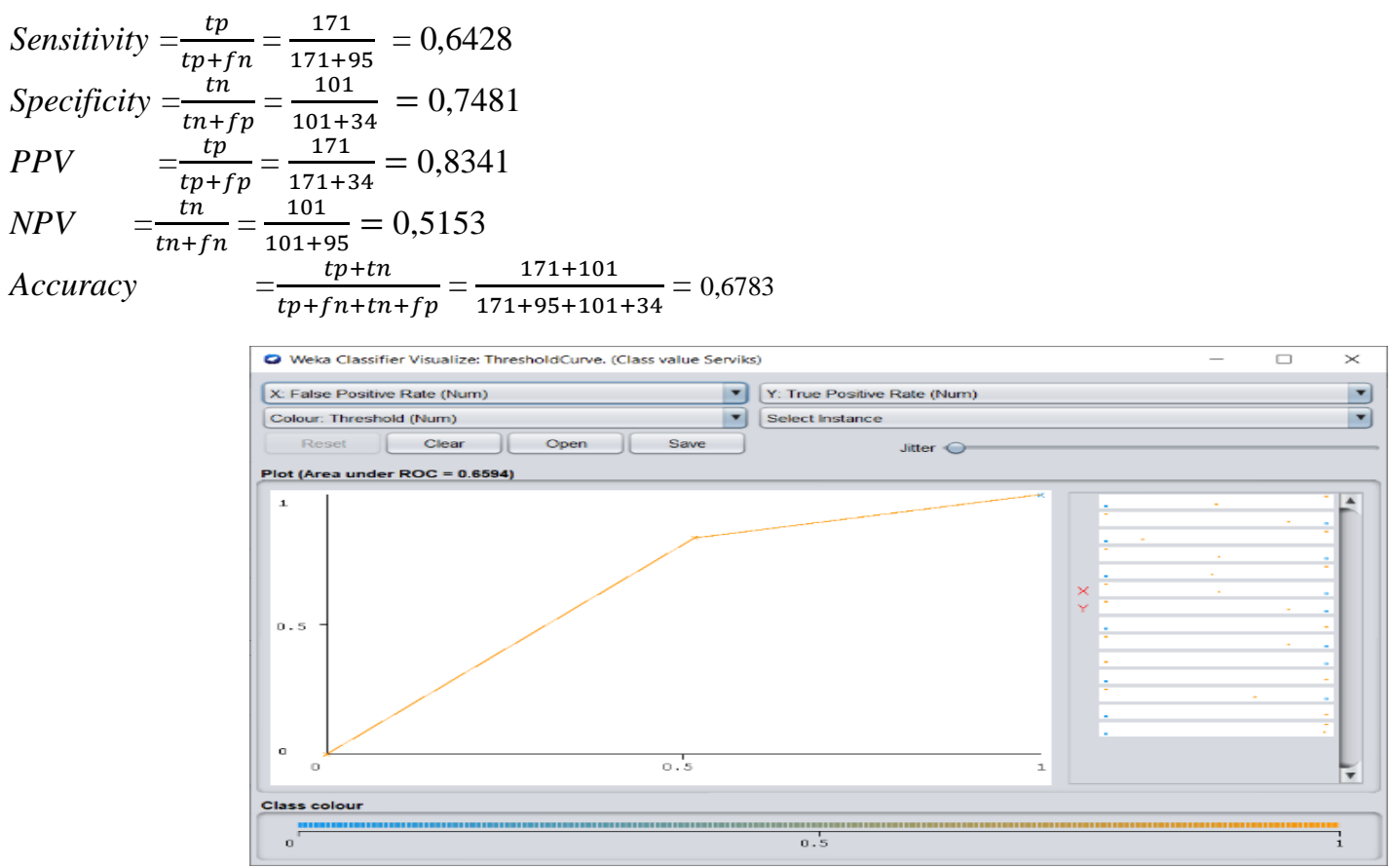

Gambar 4. Hasil AUC Dalam Grafik ROC Algoritma K-Means Manhattan

Tabel 4. Nilai accuracy, sensitivity, specificity, $p p v, n p v$ dan $R O C$

\begin{tabular}{cccc}
\hline \multicolumn{2}{c}{ K-Means Eulidean $(\%)$} & \multicolumn{2}{c}{ K-Means Manhattan (\%) } \\
\hline Accuracy & 79,30 & Accuracy & 67,83 \\
Sensitivity & 76,99 & Sensitivity & 64,28 \\
Specificity & 82,28 & Specificity & 74,81 \\
PPV & 84,87 & $P P V$ & 83,41 \\
Npv & 73,46 & $N p v$ & 51,53 \\
ROC & 79,17 & ROC & 65,94 \\
\hline
\end{tabular}




\section{KESIMPULAN}

Dari penelitian yang sudah dilakukan, yaitu mengevaluasi kinerja algoritma $K$-means pada dataset kanker serviks berdasarkan perhitungan jarak Euclidean dan Manhattan. Pada gambar 4 dan 5 menunjukkan bahwa kluster yang terbentuk dari kedua metode memiliki kemiripan dalam jumlah kluster benar sebagai serviks ( $t p)$, sedangkan kluster yang salah yang seharusnya bukan serviks tetapi masuk ke dalam kluster serviks $(f p)$ metode Euclidean memiliki hasil yg lebih baik. Dari penelitian ini dapat disimpulkan algoritma $K$-Means dengan metode perhitungan jarak Euclidean memiliki akurasi yang terbaik dibandingkan dengan metode perhitungan jarak Manhattan. Nilai akurasi yang didapat $79,30 \%$ dengan kurva ROC 79,17\% pada K-Means Euclidean Metric, sedangkan K-Means Manhattan Metric sebesar 67,83\% dengan kurva ROC 65,94\%.

\section{REFERENCES}

[1] B. Budiman, Y. Mulyana Hidayat, and A. Budi Harsono, "Evaluasi Program Deteksi Dini Kanker Serviks dengan Metode See and Treat di Kabupaten Karawang," Indones. J. Obstet. Gynecol. Sci., vol. 2, no. 1, pp. 72-80, 2019, doi: 10.24198/obgynia.v2n1.77.

[2] A. Rosiana and N. Tiara, "Pengaruh Psikoedukasi Keluarga Terhadap Kemampuan Perawtan Kebersihan Diri Pada anak Retardasi Mental Di SDLB P urwosari Kudus Tahun 2015," Indones. J. Perawat, vol. 2, no. I, pp. 50-56, 2017, [Online]. Available: https://jurnal.ugm.ac.id/buletinpsikologi/article/view/12679.

[3] P. A. Cohen, A. Jhingran, A. Oaknin, and L. Denny, "Cervical cancer," Lancet, vol. 393, no. 10167, pp. 169-182, 2019, doi: 10.1016/S0140-6736(18)32470-X.

[4] C.-J. Chen et al., Epidemiology of Virus Infection and Human Cancer BT - Viruses and Human Cancer: From Basic Science to Clinical Prevention. 2021.

[5] S. Rio, E. Sri, and T. Suci, "Persepsi tentang Kanker Serviks dan Upaya Prevensinya pada Perempuan yang Memiliki Keluarga dengan Riwayat Kanker," J. Kesehat. Reproduksi, vol. 4, no. 3, pp. 159-169, 2017, doi: 10.22146/jkr.36511.

[6] D. Makassari, "Sebaran Kanker di Indonesia, Riset Kesehatan Dasar 2007," Indones. J. Cancer, vol. 11, no. 29, pp. 1-8, 2017, [Online]. Available: https://media.neliti.com/media/publications/197251-ID-sebaran-kanker-di-indonesia-risetkeseha.pdf.

[7] I. H. Witten, Data Mining (Fourth Edition). 2017.

[8] A. Javed, B. S. Lee, and D. M. Rizzo, “A benchmark study on time series clustering," arXiv, vol. 1, no. June, p. 100001, 2020, doi: 10.1016/j.mlwa.2020.100001.

[9] N. Nidheesh, K. A. Abdul Nazeer, and P. M. Ameer, "An enhanced deterministic K-Means clustering algorithm for cancer subtype prediction from gene expression data," Comput. Biol. Med., vol. 91, pp. 213-221, 2017, doi: 10.1016/j.compbiomed.2017.10.014.

[10] S. Kapil and M. Chawla, "Performance Evaluation of K-means Clustering Algorithm with Various Distance Metrics," 1 st IEEE Int. Conf. Power Electron. Intell. Control Energy Syst., vol. 110, no. 11, pp. 12-16, 2016, doi: 10.5120/193600929.

[11] D. P. P. Mesquita, J. P. P. Gomes, A. H. Souza Junior, and J. S. Nobre, "Euclidean distance estimation in incomplete datasets," Neurocomputing, vol. 248, pp. 11-18, 2017, doi: 10.1016/j.neucom.2016.12.081.

[12] M. Nishom, "Perbandingan Akurasi Euclidean Distance, Minkowski Distance, dan Manhattan Distance pada Algoritma K-Means Clustering berbasis Chi-Square," J. Inform. J. Pengemb. IT, vol. 4, no. 1, pp. 20-24, 2019, doi: 10.30591/jpit.v4i1.1253.

[13] D. T. Larose and C. D. Larose, Data Mining and Predictive Analytics, Second. New Jersey: Wiley, 2015.

[14] C. Yuan and H. Yang, "Research on K-Value Selection Method of K-Means Clustering Algorithm," J, vol. 2, no. 2, pp. 226-235, 2019, doi: 10.3390/j2020016.

[15] J. L. Suárez, S. García, and F. Herrera, "A tutorial on distance metric learning: Mathematical foundations, algorithms, experimental analysis, prospects and challenges," Neurocomputing, vol. 425, pp. 300-322, 2021, doi: 10.1016/j.neucom.2020.08.017.

[16] G. Florin, Data Mining Concepts,Models and Techniques. Berlin: Springer, 2011. 